\title{
Dampak Distributed Energy Resources terhadap Profil Tegangan dan Rugi Daya Penyulang Bantul 05
}

\author{
Muhammad Yusuf Falah ${ }^{1}$, Adib Muhammad Arrasyid ${ }^{2}$, Afrida Nurul Ulfa ${ }^{3}$, \\ Rizal Zulfiqri Ahmad ${ }^{4}$, Jimmy Trio Putra ${ }^{5}$ \\ 1,2,3,4,5 Departemen Teknik Elektro dan Informatika, Sekolah Vokasi, Universitas Gadjah Mada, Yogyakarta, Indonesia \\ ${ }^{1}$ muhammadyusuf00@mail.ugm.ac.id*,2 arrasyidmuhammad77@mail.ugm.ac.id, ${ }^{3}$ afrida.nurul.ulfa@mail.ugm.ac.id, \\ ${ }^{4}$ rizal.z.a@mail.ugm.ac.id, ${ }^{5}$ jimmytrioputra@ugm.ac.id \\ * corresponding author
}

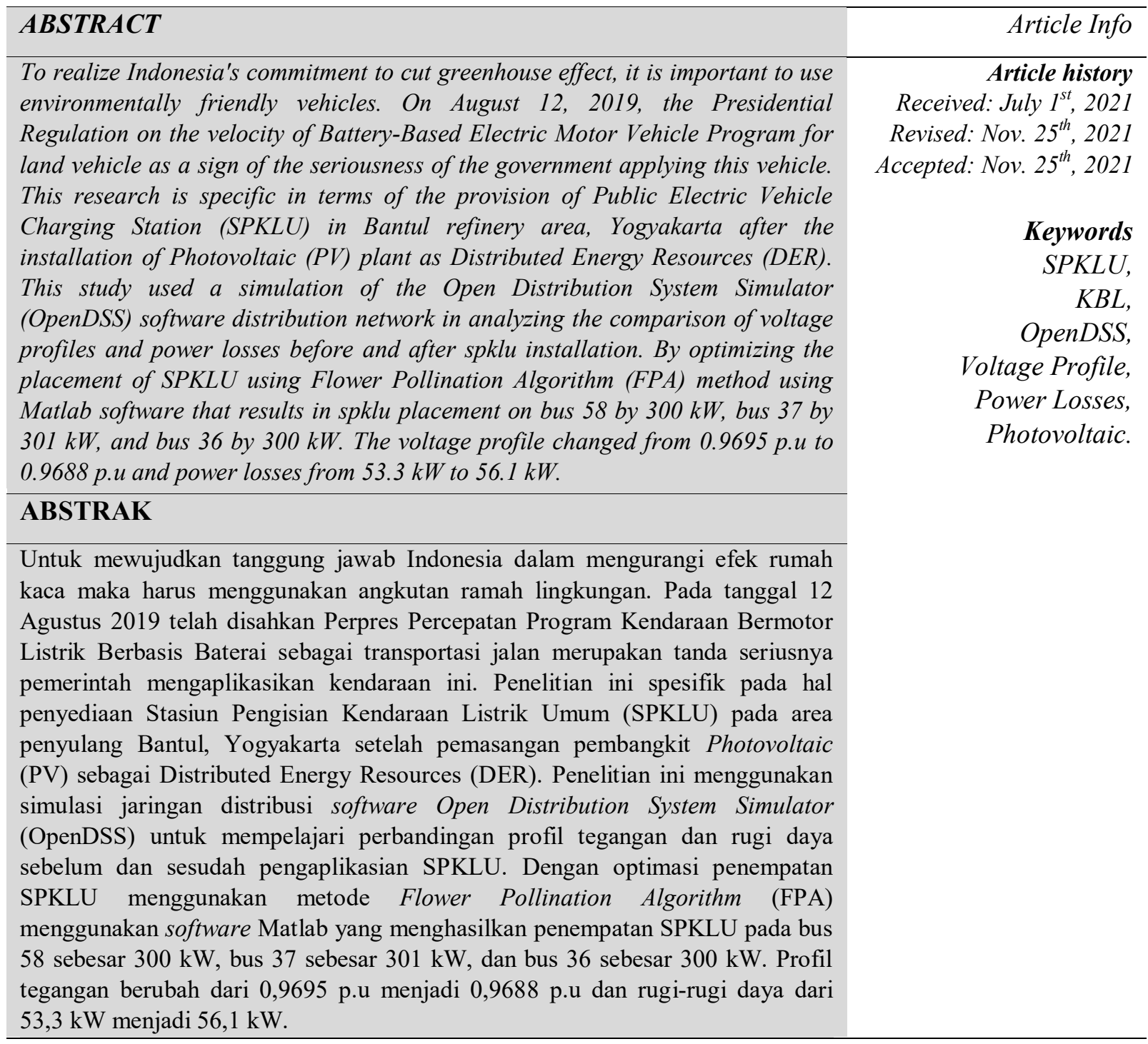




\section{PENDAHULUAN}

Transportasi adalah kegiatan memindahkan penumpang ataupun barang antar tempat, dimana hal ini mengandung unsur pergerakan. Dewasa ini, kebutuhan pada sektor transportasi terjadi peningkatan, dengan persentase rata-rata sebesar $11,5 \%$ per tahun dalam 10 tahun terakhir. Hal ini selaras dengan peningkatan penggunaan bahan bakar minyak untuk kendaraan bermotor sebesar 5\%, dimana sebagian besar BBM yang digunakan diperoleh melalui kegiatan impor. Kedua hal ini berkontribusi pada penurunan indeks kualitas udara, dikarenakan penggunaan BBM dapat meningkatkan kadar $\mathrm{CO}^{2}$ sebagai penyebab terjadinya efek rumah kaca.

Di sisi lain, memandang kendaraan listrik memiliki potensi signifikan untuk pengurangan impor BBM yang dapat meningkatkan ketahanan energi, dan dapat meningkatkan kualitas udara dengan berkurangnya emisi karbon. Hal ini sebagai jalan keluar terhadap ketergantungan penggunaan dari BBM sangat memberi harapan untuk ketahanan energi bangsa Indonesia ke depannya. Sehingga implementasi Kendaraan Listrik secara efektif dapat mengurangi efek rumah kaca di bagian hilir manajemen energi pada sektor transportasi. Target jumlah kendaraan listrik (mobil listrik sebanyak 2.200 unit, mobil hybrid sebanyak 711.900 unit, dan motor listrik sebanyak 2.130.00 unit) dan Stasiun Pengisian Kendaraan Listrik Umum (SPKLU) sebanyak 1000 unit untuk tahun 2025 (G.A Widyaningsish, 2017: 139-152).

Penelitian ini mengkaji mengenai persiapan pemenuhan Infrastruktur Kendaraan Listrik atau dikenal sebagai Stasiun Pengisian Kendaraan Listrik Umum (SPKLU) yang terdiri dari berbagai subsistem Fast Charging, dimana instalasinya harus mengimbangi perkembangan unit Kendaraan Listrik di suatu daerah tertentu. Pada penelitian ini, menggunakan data spesifikasi dan peralatan yang diambil dari jaringan penyulang Bantul 05 Yogyakarta yang terintegrasi pembangkit PV sebagai DER dalam menganalisis pengaruh integrasi EV charger atau SPKLU Kendaraan Listrik terhadap profil tegangan dan rugi daya dengan menggunakan mode aliran daya.

Pada sistem distribusi tenaga listrik analisis aliran daya dapat dilakukan dengan metode konvensional seperti Gauss Seidel Method, New Raphson Method, dan Fast Decoupled Method. Namun metode-metode konvensional tersebut dinilai kurang efektif dan memiliki level keandalan yang cenderung rendah dalam menghitung kompleks untuk sistem distribusi radial seperti penyulang Bantul 05 Yogyakarta ini yang memakai konfigurasi jaringan radial dalam 18 penyulang menyuplai beban di wilayah Kabupaten Bantul dan sekitarnya. Peneliti menganalisis aliran daya pada penambahan SPKLU yang terintegrasi pada jaringan penyulang Bantul 05 Yogyakarta setelah terintegrasi Distributed Energy Resource (DER) menggunakan software Open Disrtribution System Simulator (OpenDSS) (J.T Putra, 2019: 72-74). Data spesifikasi peralatanperalatan distribusi dan data karakter beban yang fluktuatif diambil riil dari salah satu penyulang di Bantul, Yogyakarta.

\section{METODE}

\section{Penentuan Tipe dan Letak CS}

Di dalam penentuan letak dan tipe CS diperlukan data meliputi spesifikasi EV yang sesuai target pasar yang banyak digunakan (Tabel 2), kemudian pemenuhan pengecasan dengan menggunakan tipe charging yang sesuai dengan kebutuhan spesifikasi dari EV.

Dari spesifikasi tersebut dapat diketahui variable yang dapat dijadikan parameter. Kemudian dilakukan penempatan CS melalui simulasi dari Software MATLAB dengan metode FPA di data penyulang 05 Bantul. 


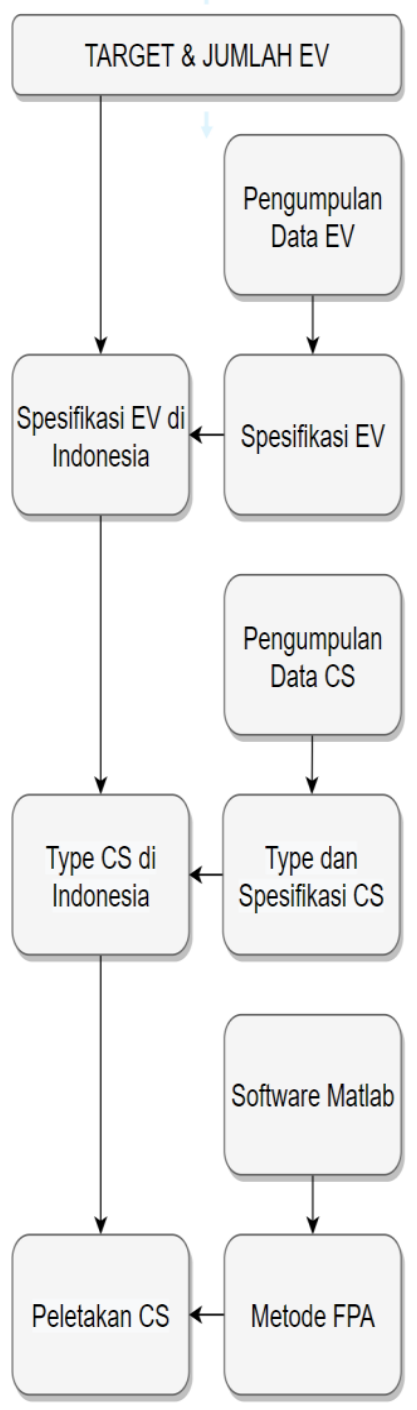

Gambar 1. Skema Penentuan Letak CS

\section{All Electric Vehicle (AEV)}

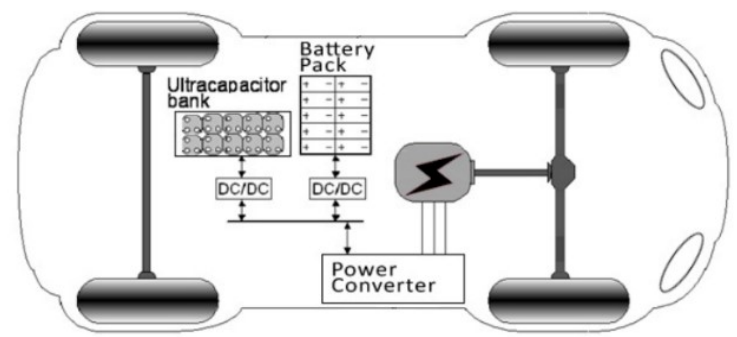

Gambar 2. All Electric Vehicle (AEV) atau

Battery Electric Vehicle (BEV) (C. Mahmoudi, 2014: 36).

All Electric Vehicle (AEV) atau Battery Electric Vehicle (BEV) menggunakan baterai berkapasitas tinggi dan motor listrik untuk penggerak (Gambar 2.). Untuk jenis ini pasokan daya diperoleh melalui baterai dan tidak terdapat tambahan mesin yang menggunakan BBM. Satu-satunya cara untuk mengisi ulang baterainya adalah dengan menghubungkan kendaraan ke titik pengisian daya. (C. Mahmoudi, 2014: 36).

\section{Hybrid Electric Vehicle (HEV)}

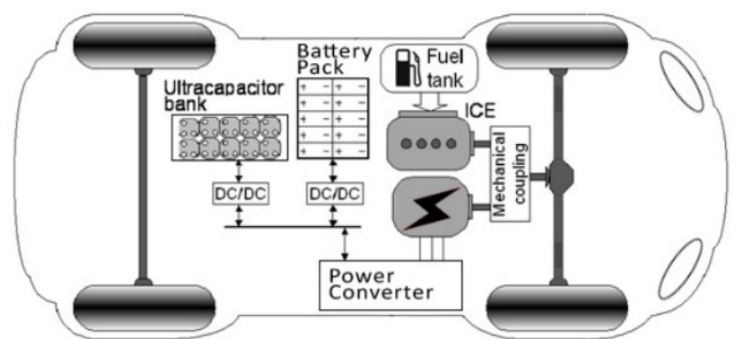

Gambar 3. Hybrid Electric Vehicle (HEV) (C. Mahmoudi, 2014: 36).

HEV memiliki power source sebuah motor elektrik (Electric Motor) atau motor listrik berIEC (Internal Combytion Engine) dapat disebut dengan diesel motor (Gambar 3). Inovasi ini dapat dipakai untuk masalah energy crisis dan air pollution di kota-kota. Susunan HEV ini tersusun dati satu ICE, satu generator, battery, dan electric motor. Susunan HEV didistribusikan menjadi PHEV atau Parallel Hybrid Electric Vehicle, SPHEV atau SeriesParallel Hybrid Electric Vehicle, dan SHEV atau Series Hybrid Electric Vehicle. Susunan ini berdampak di distribusi kerja dua motor ICE dan DC motor sebagai EM.

\section{Charging Station (CS)}

Charging station adalah alat untuk mengisi daya baterai pada EV. Waktu yang diperlukan untuk mengisi daya baterai bergantung sisi tegangan ataupun arus yang dihasilkan alat pengisi daya, ketika arus ataupun tegangannya rendah maka waktu mengisi daya akan lebih lama, lalu ketika arus ataupun tegangannya tinggi maka waktu pengisian daya akan lebih cepat.

Charging station memiliki klasifikasi yaitu $D C$ Fast Charge (DCFC), AC level 2, dan $A C$ level 1. Klasifikasi tersebut berkaitan alat untuk mengisi daya baterai $E V$. Ketika level mengisi 
semakin tinggi maka waktu mengisi akan lebih singkat (F.S.Kamajaya, 2015: 163-166).

Tabel 1. Level Charging Station

\begin{tabular}{ccccc}
\hline Level & $\begin{array}{c}\text { AC } \\
\text { Supply } \\
(\mathrm{V})\end{array}$ & $\begin{array}{c}\text { Arus } \\
\text { Maks } \\
(\mathrm{A})\end{array}$ & $\begin{array}{c}\text { Daya } \\
\text { Maks } \\
(\mathrm{kW})\end{array}$ & $\begin{array}{c}\text { Charger } \\
\text { Location }\end{array}$ \\
\hline $\begin{array}{c}\text { AC } \\
\text { Level 1 } \\
\text { AC }\end{array}$ & 120 & 12 & 1,44 & $\begin{array}{c}\text { Onboard 1- } \\
\text { fasa } \\
\text { Level 2 } \\
\text { DC }\end{array}$ \\
Level 3 & 240 & 32 & 7,7 & $\begin{array}{c}\text { Onboard 1/3 } \\
\text { fasa } \\
\text { Offboard 3- } \\
\text { fasa }\end{array}$ \\
\hline
\end{tabular}

\section{AC level 1}

$A C$ level 1 Charging adalah alat mengisi daya yang paling sering digunakan, dimana menggunakan standard residensial dengan voltase 120 volt. Sebagian besar pabrikan $E V$ menggunakan $A C$ level 1 EVSE untuk standar sehingga tanpa memerlukan additional part. Pada pengisian daya dengan $A C$ level 1 selama 60 menit dapat menambah kurang lebih $6 \mathrm{~km}$ jarak tempuh perjalanan.

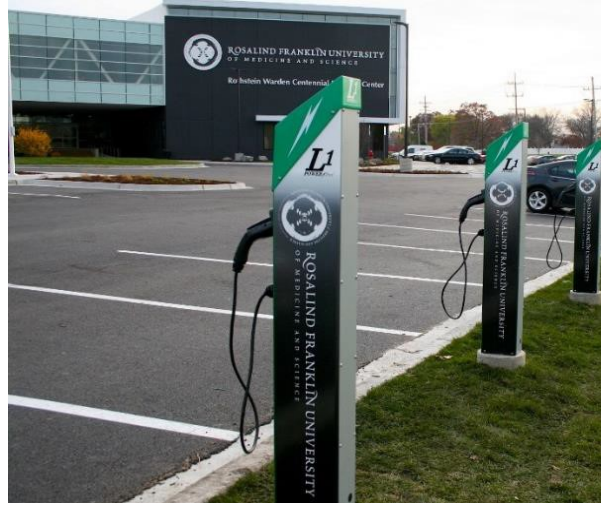

Gambar 4. CS level 1 (New West Technologies, 2015: 18).

\section{AC level 2}

$A C$ Level 2 Charging membutuhkan residensial dengan 220-240 volt. Pada pengisian ulang menggunakan $A C$ Level 2 dengan lama pengisian 60 menit dapat menambah kurang lebih $25 \mathrm{~km}$ perjalanan untuk angkutan pada $3.3 \mathrm{~kW}$ onboard charger, atau $50 \mathrm{~km}$ untuk kendaraan dengan $6.6 \mathrm{~kW}$ onboard charger. Perangkat ini mampu digunakan dalam mengisi daya yang lebih singkat, tetapi diperlukan ahli dalam penataan listrik dan kesesuaian penggunaan sirkuit kelistrikan.

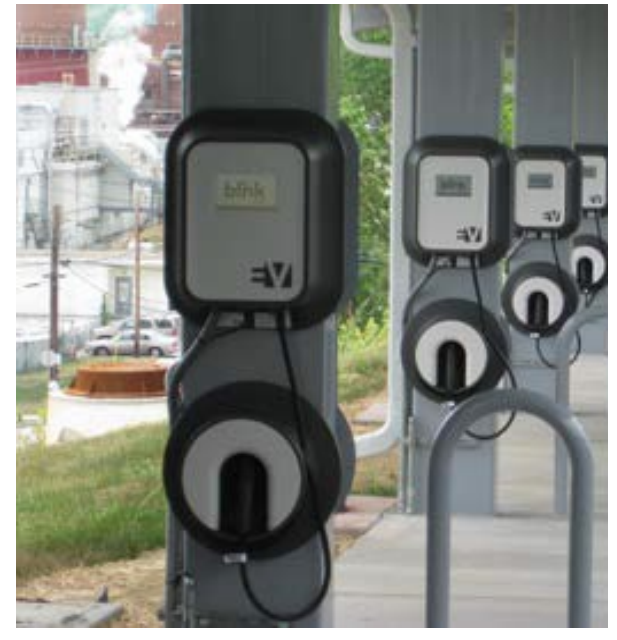

Gambar 5. CS level 2 (New West Technologies, 2015: 8).

\section{Fast Charging (DCFC)}

$D C F C$ merubah $A C$ current menjadi $D C$ current pada peralatan EVSE, sehingga menyediakan arus searah (DC) yang memiliki daya tinggi dengan memotong jalur charger mobil untuk langsung menuju traction baterai $E V$ melewati inlet pengisian pada kendaraan. Peralatan DCFC menggunakan komersial dengan 480-volt $A C$ power service. Pada pengisian ulang selama 20-30 menit DCFC dapat menambah kurang lebih 130-160 km jarak tempuh perjalanan. (D.Kettles, 2016: 424443).

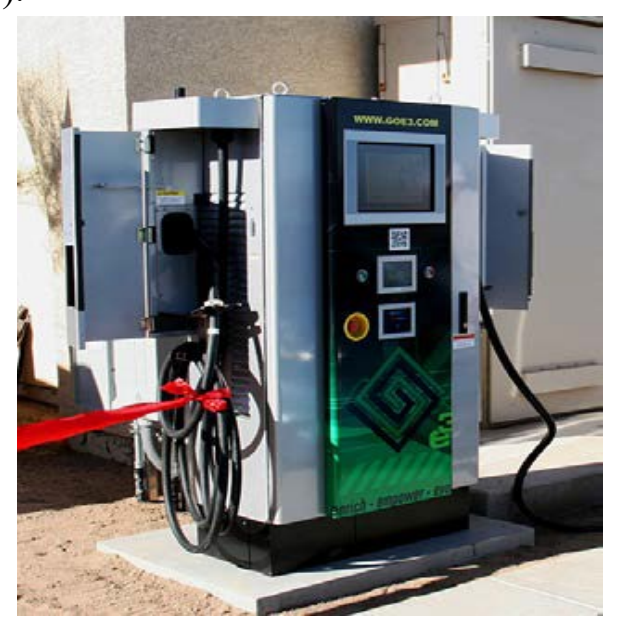

Gambar 6. CS level 1 (New West Technologies, 2015: 27).

\section{Penggunaan CS}

Untuk data load shape pada OpenDSS penggunaan $C S$ dalam 24 jam sebagai berikut : 


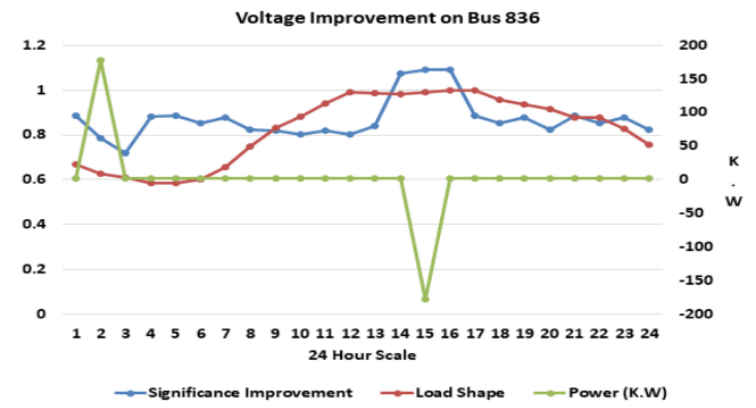

Gambar 7. penggunaan CS (M.Aqib, 2019: 223).

\section{Flower Pollination Algorithm (FPA)}

Flower Pollination Algorithm merupakan algoritma heuristik tinggi yang dapat menggantikan metode klasik (F.P. Sakti, 2019: 36-43). Beberapa fenomena penyerbukan bunga adalah sebagai berikut (F.P. Sakti, 2017: 3).

1. Penyerbukan menyeluruh (global) diketahui sebagai penyerbukan silang dan penyerbukan biotik, yaitu organisme penyerbuk yang membawa serbuk sari dengan gerak Lévy Flights.

2. Penyerbukan domestik (lokal) diketahui sebagai penyerbukan sendiri dan penyerbukan abiotik.

3. Flower constancy diketahui untuk probabilitas reproduksi yang seimbang dengan persamaan dari keterlibatan dua buah bunga.

4. Penyerbukan global dan lokal diatur oleh peluang berpindah.

Dalam algoritma ini mencakup dua pijakan inti, yaitu penyerbukan domestik dan penyerbukan menyeluruh. Ketika penyerbukan menyeluruh, serbuk sari yang bermula pada bunga diangkut oleh organisme yang menyerbuk, dan serbuk sari dapat menjalankan jalan jarak jauh dikarenakan organisme penyerbuk dimungkinkan berpindah-pindah di tempat yang lapang. Pada jalan tersebut dapat mengeluarkan solusi teroptimal yang ditampilkan pada regulasi pertama, dan direpresentasikan secara matematis dengan fenomena flower constancy sebagai berikut : ( M.R. Djalal, 2017: 3).

$x_{\mathrm{i}}^{\mathrm{t}+1}=x_{\mathrm{i}}^{\mathrm{t}}+\gamma \mathrm{L}(\lambda)\left(x_{\mathrm{i}}^{\mathrm{t}}-\mathrm{g}^{*}\right)$ $x_{\mathrm{i}}^{\mathrm{t}}$ : vektor solusi $x_{\mathrm{i}}$ atau serbuk sari i di iterasi t, $\mathrm{g}^{*}$ : hasil paling baik dari iterasi yang berjalan.

$\mathrm{L}$ : kekuatan dari penyerbukan, merupakan besar langkah.

Pada aturan kedua atau polinasi lokal, representasi dari hubungan spesifik bunga sebagai berikut :

$\mathrm{x}_{\mathrm{i}}^{\mathrm{t}+1}=x_{\mathrm{i}}^{\mathrm{t}}+\in\left(x^{t}-x^{t}{ }_{k}\right)$

$x^{t}{ }_{j}$ dan $x^{t_{k}}$ : serbuk sari yang memiliki asal bunga yang lain dengan jenis sama.

Secara matematis, jika $x^{t}{ }_{j}$ dan $x^{t}{ }_{k}$ dipilih dari populasi serupa atau datang dari jenis yang serupa, jika harga $\epsilon$ adalah pendistribusi serupa 0 sampai 1, maka akan menjadi tahap acak lokal.

\section{Analisa Aliran Daya}

Di awal memasukan variabel titik bus, daya, dan impedans atau beban yang telah diketahui dari sebuah diagram satu garis, kemudian membuat permodelan jaringan distribusinya dalam suatu software ETAP 12.6.

Dari model jaringan distribusi yang ada dibuat bahasa pemrograman di OpenDSS untuk bahan data analisa profil tegangan dan rugi-rugi daya nantinya. Pada bahasa pemrograman Matlab digunakan untuk menjalankan metode Flower Pollination Algorithm dengan data-data variabel titik bus, daya, dan impedans atau beban dari OpenDSS, sehingga terjalin komunikasi data antara OpenDSS dengan Matlab, yaitu OpenDSS sebagai sumber data metode dan Matlab sebagai operasi metode Flower Pollination Algorithm. Kemudian menjalankan simulasi dengan dua model yaitu dengan menambahkan generator terdistribusi pada bus 33 dan bus 19 di OpenDSS dan pada model kedua dengan menambahkan generator terdistribusi pada bus terebut serta menambahkan letak dan kapasitas stasiun pengisian kendaraan listrik di OpenDSS. Dimana letak dan kapasitas stasiun pengisian kendaraan listrik diperoleh dari hasil operasi metode Flower Pollination Algorithm oleh Matlab. 
Setelah semua variabel dimasukkan dapat melakukan analisa profil tegangan dan rugi daya menggunakan software OpenDSS. Kemudian didapatkan hasil penelitian profil tegangan dan rugi-rugi daya yang sebaik mungkin.

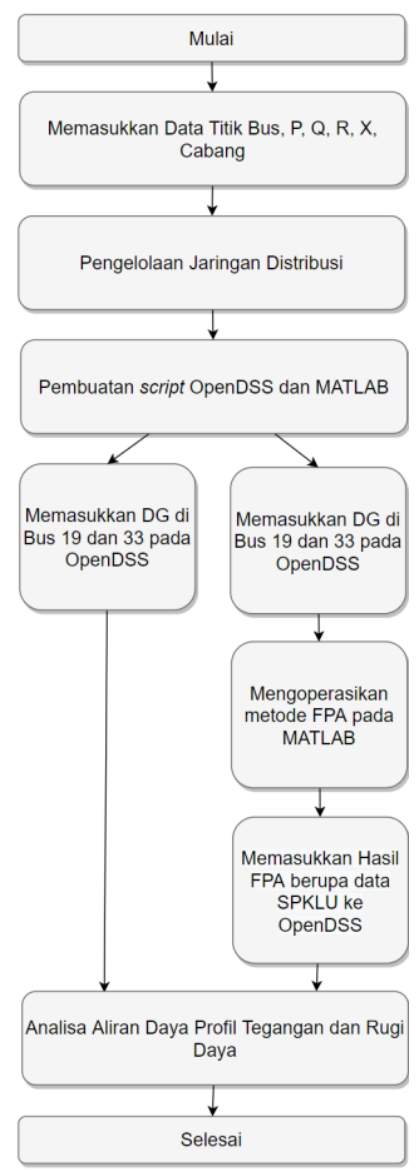

Gambar 8. Skema Penelitian

\section{OpenDSS}

OpenDSS adalah software simulasi untuk jaringan distribusi yang pertama kali dikembangkan pada tahun 1997 oleh Electrotek Concepts. Pada tahun 2004, OpenDSS diakuisisi oleh EPRI (Electric Power Research Institute) sehingga dijadikan Open Source pada tahun 2008 yang diprogram dalam Delphi untuk dijalankan sebagai software sendiri pada basis sistem operasi windows dan dapat diintegrasikan dengan perangkat lunak lain seperti Excel, Pyhthon, dan Matlab (D.W. Gao, 2017: 3-4).

Untuk mensimulasi suatu rangkaian, OpenDSS memiliki fleksibilitas tinggi dalam pengolahan program dapat mempertimbangkan banyak elemen, seperti, elemen pengukuran, elemen umum, elemen kontrol, elemen penghantar, dan elemen konversi yang dapat digambarkan melalui diagram (gambar 9). OpenDSS diintegrasikan dengan software pihak ketiga yang lainya melalui sebuah jalur komunikasi antarmuka, dan dibutuhkan penulisan pengguna untuk mendapatkan elemen-elemen tersebut (D.W. Gao, 2017: 3-5).

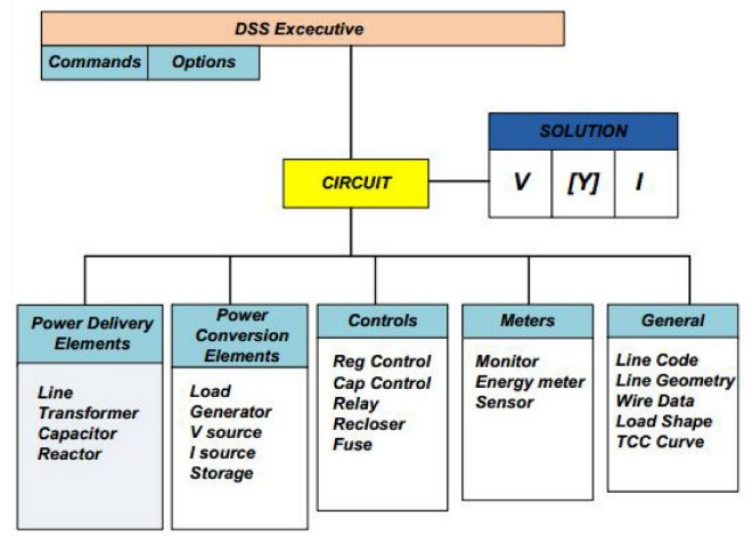

Gambar 9. Bagan cara kerja simulasi OpenDSS

OpenDSS memiliki fitur seperti Grid Elements yang dapat mensimulasikan suatu jaringan distribution power grid dengan variabel generation seperti kalkulasi shortcircuit, kalkulasi rugi daya, manajemen penyimpanan, dan beban tidak seimbang. Kemudian fitur analisa aliran daya untuk tipe jaringan mesh dan radial, kemudian terdapat capacitor bank control untuk pengaturan bank kapasitor, kemudian terdapat analisa harmonik pada arus dan tegangan di suatu jaringan distribusi, lalu memiliki analisa transien di jaringan distribusi maupun microgrids, dan memiliki analisa regulasi tegangan (D.W. Gao, 2017: 3-5).

Pada penelitian ini digunakan analisa aliran daya dengan suatu sistem iterasi yang berulang dan mempertimbangkan elemen penghantar seperti kabel, kapasitor, reaktor, dan transformator serta mempertimbangkan elemen konversi seperti sumber arus, sumber tegangan, reaktor, generator, dan beban. Dimana pengolahan elemen-elemen tersebut dapat digambarkan seperti berikut: 


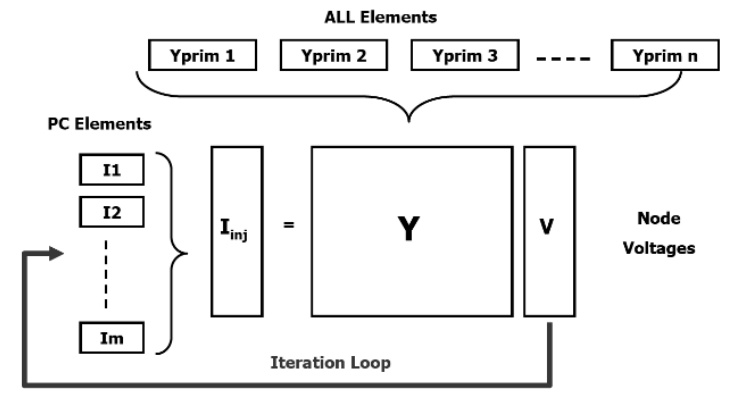

Gambar 10. Bagan iterasi solusi OpenDSS (R.C Dugan, 2013: 1-177).

Untuk pencarian solusi difokuskan pada sistem nonlinier admitansi dengan rumus berikut : $\quad \boldsymbol{I}_{\text {inj }}(\boldsymbol{V})=\boldsymbol{Y}_{\text {system }} \boldsymbol{V}$

Dimana merupakan injeksi atau kompensasi elemen konversi yang dimungkinkan pada elemen nonlinier.

\section{Photovoltaic}

Grid terkoneksi photovoltaic (PV) solar panel adalah pembangkit listrik tenaga matahari. Solar panel module dapat menjadikan energi matahari menjadi DC current. DC current yang diproduksi kemudian didistribusi dengan power converter yang menjadikan $A C$ current, dimana dengan sendirinya akan mengatur sistem keseluruhan. AC current akan disebarkan lewat hubung bagi distribusi lalu mengalirkan listrik di sistem distribusi. Data photovoltaic power yang dihasilkan dari mengamati dan mengukur tiap harinya di Quensland University dapat dilihat pada gambar berikut, (UQ Solar photovoltaic data, 2019).

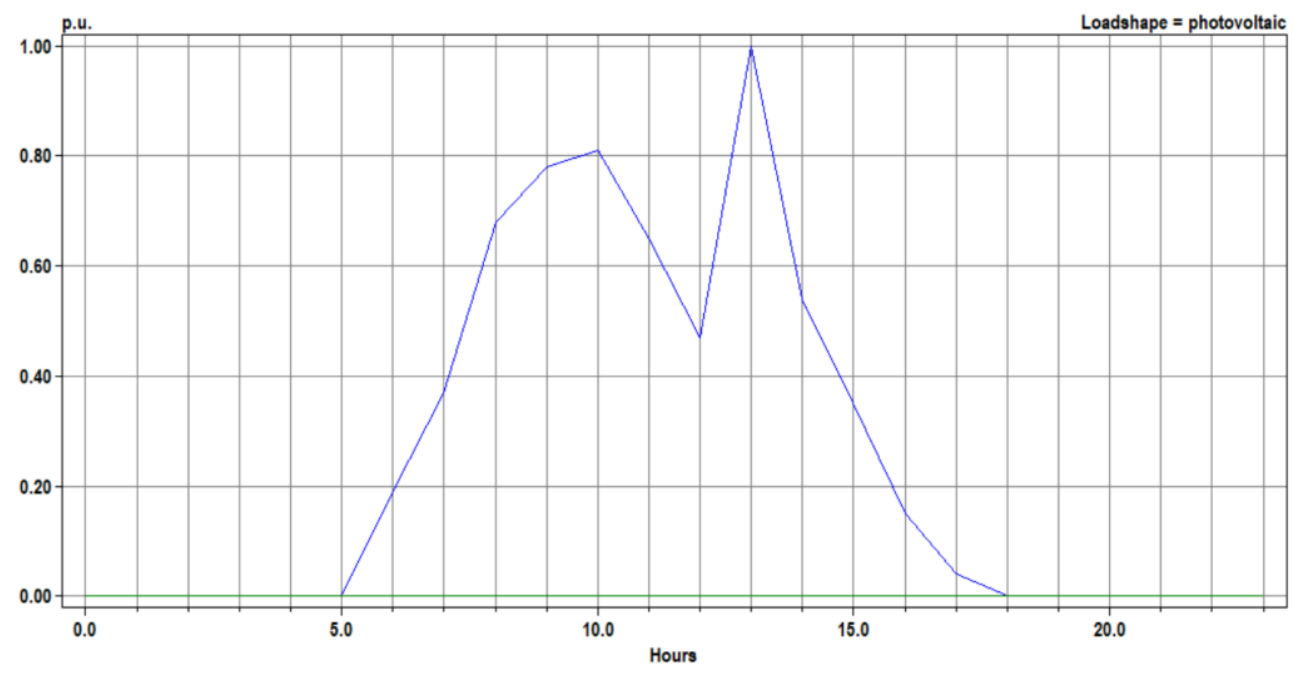

Gambar 11. Kurva profil daya output PV

\section{Penyulang Bantul 05}

Data penelitian ini berasal dari penyulang GI Bantul 05 Yogyakarta. Berikut diagram penyulang Bantul 05 di Yogyakarta setelah diintegrasikan dengan DG pada bus 19 dan 33: 


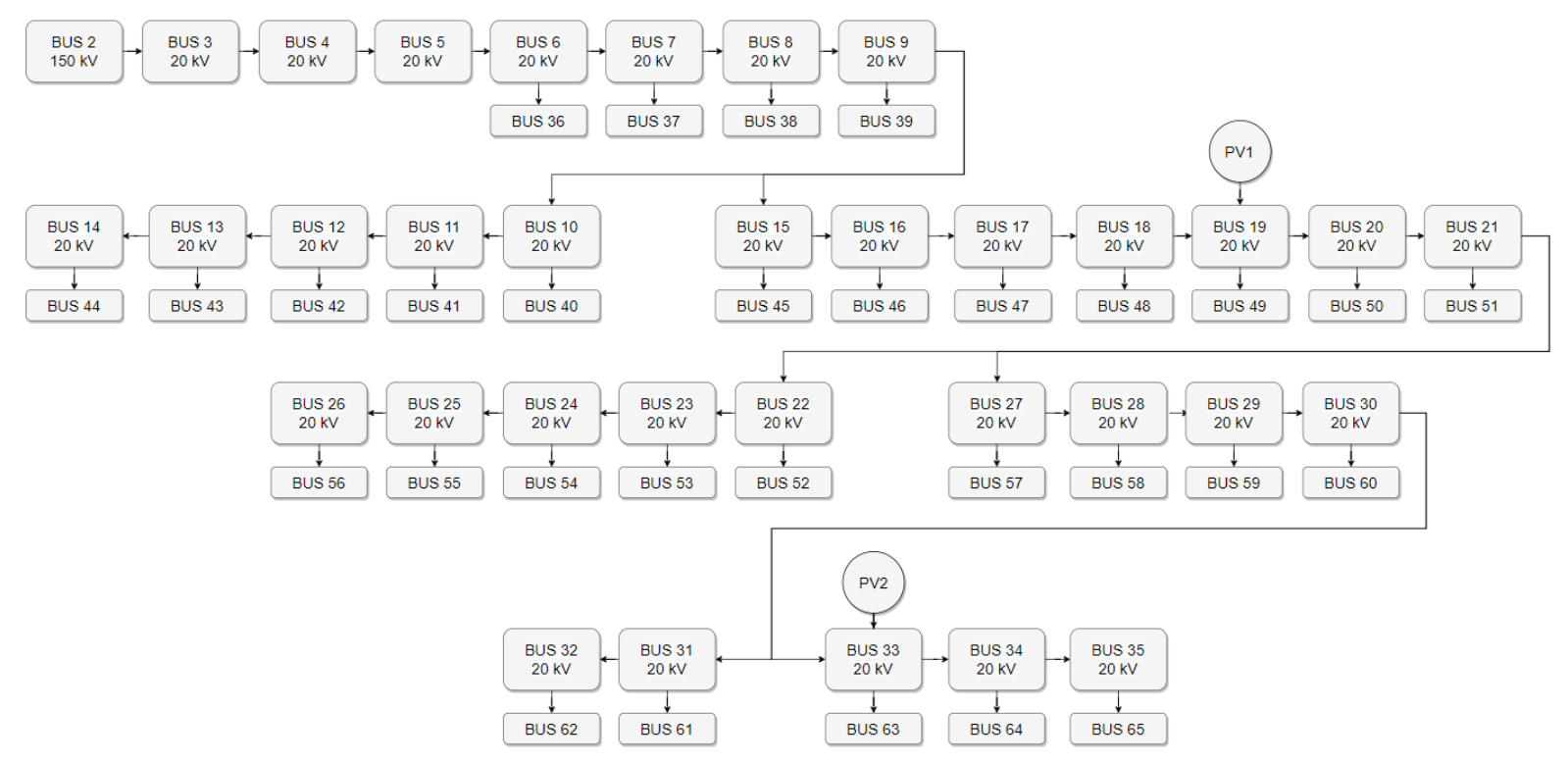

Gambar 12. Data penyulang Bantul 05 (J.T Putra, 2019: 74).

\section{HASIL DAN PEMBAHASAN}

Pada analisis data penjualan mobil listrik di Indonesia diperoleh jenis dan spesifikasi EV yang banyak digunakan (H.S Das, 2020: 36). Berikut spesifikasi EV :

Tabel 2. Spesifikasi EV

\begin{tabular}{|c|c|c|c|c|}
\hline Parameter & $\begin{array}{c}\text { Toyota } \\
\text { Plug-in } \\
\text { Prius }\end{array}$ & $\begin{array}{l}\text { Exora } \\
\text { REEV }\end{array}$ & $\begin{array}{c}\text { Honda Fit- } \\
\text { EV }\end{array}$ & $\begin{array}{c}\text { Mitsubish } \\
\text { i-MiEV }\end{array}$ \\
\hline Type & $\begin{array}{l}\text { Plug-In } \\
\text { hybrid }\end{array}$ & $\begin{array}{c}\text { Plug-In } \\
\text { hybrid }\end{array}$ & Battery & Battery \\
\hline $\begin{array}{l}\text { Jarak } \\
\text { tempuh } \\
(\mathrm{Km})\end{array}$ & 24 & 97 & 131 & 160 \\
\hline $\begin{array}{l}\text { Kapasitas } \\
\text { baterai } \\
(\mathrm{kWh})\end{array}$ & 4,4 & 13,5 & 20 & 16 \\
\hline $\begin{array}{l}\text { Onboard } \\
\text { Charger } \\
(\mathrm{kW})\end{array}$ & 1,44 & 3,8 & 6,6 & 2,3 \\
\hline $\begin{array}{l}\text { Quick } \\
\text { charger } \\
(k W)\end{array}$ & 3,3 & 20 & 40 & 50 \\
\hline $\begin{array}{l}\text { Waktu } \\
\text { pengecasan }\end{array}$ & $\begin{array}{c}\text { Onboard: } \\
3 \text { jam } \\
\text { Quick } \\
: 1,5 \text { jam }\end{array}$ & $\begin{array}{l}\text { Onboard } \\
: 4 \text { jam } \\
\text { Quick } \\
: 0,5 \text { jam }\end{array}$ & $\begin{array}{c}\text { Onboard: } \\
3 \text { jam } \\
\text { Quick } \\
: 0,5 \text { jam }\end{array}$ & $\begin{array}{c}\text { Onboard } \\
8 \text { jam } \\
\text { Quick } \\
: 0,5 \text { jam }\end{array}$ \\
\hline
\end{tabular}

Dari spesifikasi EV diperoleh type CS yang sesuai untuk pemenuhan kebutuhan level pengecasan $(\mathrm{kW})$ pada SPKLU (A.Bahrami, 2020: 36). Diperoleh tipe CS sebagai berikut:
Tabel 3. Type dan Spesifikasi $C S$

\begin{tabular}{|c|c|c|c|c|}
\hline Parameter & \multicolumn{4}{|c|}{ Type 2 CCS } \\
\hline Power & \multicolumn{4}{|c|}{$\begin{array}{l}L 1 \max 3.7 \mathrm{~kW}, L 2 \max 43.5 \mathrm{~kW} \text {, } \\
\text { L3 } \max 350 \mathrm{~kW}\end{array}$} \\
\hline Convenience & \multicolumn{4}{|c|}{1.5 konektor Ukuran menengah } \\
\hline Communication & \multicolumn{4}{|l|}{ PLC } \\
\hline Flexibility & \multicolumn{4}{|c|}{$\begin{array}{l}\text { L1 \& L2; } 1 \text { phase, split phase, } 3 \\
\text { phase, DC low, DC mid L3 ; up } \\
\text { to } 850 \mathrm{~V}\end{array}$} \\
\hline Support & \multicolumn{4}{|c|}{ Europa } \\
\hline \multicolumn{5}{|c|}{$\begin{array}{l}\text { Pada penelitian dengan menggunakan } \\
\text { software OpenDSS telah didapatkan hasil profil } \\
\text { tegangan dan rugi-rugi daya setelah } \\
\text { ditambahkan Distributed Generator pada bus } \\
33 \text { dan } 19 \text { di penyulang Bantul } 05 \text {. } \\
\text { Berikut spesifikasi DG berfrekuensi } 50 \mathrm{~Hz} \\
\text { dan memiliki fasa berjumlah } 3 \text { yang di pasang } \\
\text { pada bus tersebut: }\end{array}$} \\
\hline \multicolumn{5}{|c|}{ Tabel 4. Data DG } \\
\hline DG & Bus & $\mathrm{kV}$ & $\mathrm{kW}$ & kVAR \\
\hline Photovoltaic 1 & Bus 19 & 0,38 & 2500 & 1000 \\
\hline Photovoltaic 2 & Bus 33 & & 2500 & 1000 \\
\hline
\end{tabular}

Berdasarkan hasil metode FPA didapatkan penempatan CS yang optimal pada bus 58, bus 37, dan bus 36. Berikut tabel hasil penempatan CS. 
Tabel 5. Data Penempatan CS

\begin{tabular}{lllll}
\hline Bus & $P F$ & $\mathrm{kV}$ & $\mathrm{kW}$ & $\mathrm{kVAR}$ \\
\hline Bus 58 & 0,9 & 333 & 300 & 145 \\
Bus 37 & 0,9 & 334 & 301 & 146 \\
Bus 36 & 0,9 & 333 & 300 & 145 \\
\hline
\end{tabular}

\section{Hasil Profil Tegangan}

Pada penelitian ini telah didapatkan hasil profil tegangan yang telah disimulasikan dengan software OpenDSS pada penyulang Bantul 05 Yogyakarta.

\section{Sebelum Integrasi SPKLU}

Berikut profil tegangan setelah penyulang Bantul 05 ditambahkan DG di bus 19 dan 33 :

Tabel 6. Data Profil Tegangan 1

\begin{tabular}{lll}
\hline Parameter & $\begin{array}{l}\text { Hasil di Penyulang Bantul } 05 \\
\text { Yogyakarta }\end{array}$ & \\
\hline Vmax (p.u) & 1,00 & \\
Vmin (p.u) & 0,9695 & \\
$\sum$ Pload (kW) & 6084,3 & \\
$\sum \mathrm{kW}$ loss & 53,3 & \\
\hline
\end{tabular}

\section{Sesudah Integrasi SPKLU}

Berikut profil tegangan setelah penyulang Bantul 05 ditambahkan DG di bus 19 dan 33 dan diintegrasikan dengan SPKLU :

Tabel 7. Data Profil Tegangan 2

\begin{tabular}{llll}
\hline Parameter & $\begin{array}{l}\text { Hasil di Penyulang } \\
\text { Yogyakarta }\end{array}$ & Bantul 05 \\
\hline Vmax (p.u) & 1,00 & & \\
Vmin (p.u) & 0,9688 & & \\
$\sum$ Pload (kW) & 6342,4 & & \\
$\sum \mathrm{kW}$ loss & 56,1 & & \\
\hline
\end{tabular}

\section{Hasil Rugi-Rugi Daya}

Pada penelitian ini telah didapatkan hasil rugi-rugi daya yang telah disimulasikan dengan software OpenDSS pada penyulang Bantul 05 Yogyakarta.

\section{Sebelum Integrasi SPKLU}

Berikut rugi-rugi daya setelah penyulang Bantul 05 ditambahkan DG di bus 19 dan 33 :
Tabel 8. Rugi-rugi daya 1

\begin{tabular}{ll}
\hline Parameter & $\begin{array}{l}\text { Hasil di Penyulang Bantul 05 } \\
\text { Yogyakarta }\end{array}$ \\
\hline Total losses $(\%)$ & $0,88 \%$ \\
Total losses $(\mathrm{kW})$ & 53,3 \\
Line losses $(\mathrm{kW})$ & 27,9 \\
Trafo losses $(\mathrm{kW})$ & 25,4 \\
\hline
\end{tabular}

\section{Sesudah Integrasi SPKLU}

Berikut rugi-rugi daya setelah penyulang Bantul 05 ditambahkan dan diintegrasikan dengan SPKLU:

Tabel 9. Rugi-rugi daya 2

\begin{tabular}{ll}
\hline Parameter & $\begin{array}{l}\text { Hasil di Penyulang Bantul 05 } \\
\text { Yogyakarta }\end{array}$ \\
\hline Total losses $(\%)$ & $0,88 \%$ \\
Total losses $(\mathrm{kW})$ & 56,1 \\
Line losses $(\mathrm{kW})$ & 29,2 \\
Trafo losses $(\mathrm{kW})$ & 26,9 \\
\hline
\end{tabular}

\section{SIMPULAN}

Aliran daya dengan simulasi OpenDSS pada penyulang Bantul 05 yang telah ditambahkan DG pada bus 19 dan bus 33 dengan nilai masing-masing $2500 \mathrm{~kW}$ telah memiliki profil tegangan dengan nilai terendah 0,9695 p.u dan rugi daya $53,3 \mathrm{~kW}$. Setelah dilakukan metode Flower Pollination Algorithm dihasilkan integrasi SPKLU pada bus 58 dengan nilai $300 \mathrm{~kW}$, bus 37 bernilai 301 $\mathrm{kW}$, dan bus 36 bernilai $300 \mathrm{~kW}$ memiliki voltage profile minimum $0,9688 \mathrm{p}$.u dan rugi daya 56,1. Sehingga dapat disimpulkan hasil dari penambahan SPKLU dengan metode Flower Pollination Algorithm pada penyulang Bantul 05 yang telah ditambahkan DG pada bus 19 dan bus 33 dengan nilai masing-masing $2500 \mathrm{~kW}$ memiliki pengaruh penambahan losses sebesar 3,8 kW/hari.

\section{DAFTAR RUJUKAN}

G. A. Widyaningsih. 2017. Peraturan Presiden Nomor 22 Tahun 2017 tentang Rencana Umum Energi Nasional. J. Huk. 
Lingkung. Indones., vol. 4, no. 1, pp. 139-152, doi: 10.38011/jhli.v4i1.53.

J. T. Putra, I. Istiqomah, R. Khomarudin, and A. Diantoro. 2019. Pengaruh pembangkit photovoltaic sebagai distributed energy resources terhadap profil tegangan dan rugi-rugi daya pada Penyulang Bantul 05 Yogyakarta. Tek. J. Sains dan Teknol., vol. 15, no. 2, p. 72, doi: 10.36055/tjst.v15i2.6811.

C. Mahmoudi, A. Flah, and L. Sbita. 2014. An overview of electric Vehicle concept and power management strategies. 2014 Int. Conf. Electr. Sci. Technol. Maghreb, Cist. 2014, no. November, doi: 10.1109/CISTEM.2014.7077026.

F. Sutra Kamajaya and M. Muzmi Ulya. 2015. Analisis Teknologi Charger Untuk Kendaraan Listrik - Review. J. Rekayasa Mesin, vol. 6, no. 3, pp. 163-166, doi: 10.21776/ub.jrm.2015.006.03.4.

M. Smith and J. Castellano. 2015. Costs Associated With Non-Residential Electric Vehicle Supply Equipment. U.S. Dep. Energy, no. November, pp. 1-43.

D. Kettles et al.. 2016. Electric Vehicle Sales and Future Projections. Appl. Energy, vol. 168 , no. January, pp. 434-443

M. Aqib and A. Ukil. 2019. Voltage Sensitivity Analysis and Demand Dispatch Option of Electric Vehicle in Smart Grid. 2019 IEEE PES Innov. Smart Grid Technol. Asia, ISGT 2019, pp. 218-223, doi: 10.1109/ISGT-Asia.2019.8881803.

F. P. Sakti and J. T. Putra. 2019. Optimal Reactive Power Dispatch untuk Meminimalkan Rugi Daya Menggunakan Flower Pollination Algorithm. J. Tek. Elektro, vol. 11, no. 2, pp. 36-43, doi: 10.15294/jte.v11i2.21680.
F. P. Sakti, S. Sarjiya, and S. P. Hadi. 2017. Optimal Power Flow Using Flower Pollination Algorithm: A Case Study of 500 kV Java-Bali Power System. IJITEE (International J. Inf. Technol. Electr. Eng., vol. 1, no. 2, doi: 10.22146/ijitee.28363.

M. R. Djalal, Y. Yunus, and A. Imran. 2017. Flower Pollination Algorithm Pada Pengendalian Kecepatan Motor Induksi. vol. 15 , no. 1 .

D. W. Gao, E. Muljadi, T. Tian, and M. Miller. 2017. Software Comparison for Renewable Energy Deployment in a Distribution Network. Nrel.

R. C. Dugan. 2013. Reference Guide: The Open Distribution System Simulator (OpenDSS). Electr. Power Res. Institute, Inc., no. November, pp. 1-177.

UQ solar photovoltaic data. http://solar.uq.edu.au/, 11/04/2021

H. S. Das, M. M. Rahman, S. Li, and C. W. Tan. 2020. Electric vehicles standards, charging infrastructure, and impact on grid integration: A technological review. Renew. Sustain. Energy Rev., vol. 120, no. November, doi: 10.1016/j.rser.2019.109618.

A. Bahrami. 2020. EV Charging Definitions, Modes, Levels, Communication Protocols and Applied Standards Technical Report. no. January. 